\title{
The Knowledge of Classroom Management as A Basis in Improving Hindu Religious Teacher's Performance
}

\author{
Ni Nengah Selasih ${ }^{1}$ \\ \{nghselasih@gmail.com ${ }^{1}$ \} \\ ${ }^{1}$ Posgraduate Program of Balinese Language Education, IHDN Denpasar, Indonesia

\begin{abstract}
In order to accomplish the goals of national education, the teacher holds a very significant role and responsibility, namely as the implementer of the education system. Carrying out these roles and responsibilities, the teacher must have high performance. High and low teacher performance can be affected by internal and external factors. There is a direct influence on the knowledge of teacher classroom management on the performance of teachers of Hinduism with a T-calculated value of 3.741 greater than the T-table of 1.96. In addition, the beta coefficient is 0.224 and the probability is $0.000<0.05$. That is, the higher the classroom management knowledge of the teacher, the higher the performance of the Hindu religious teacher. Conversely, the lower the classroom management knowledge of the teacher, the lower the performance of the Hindu religious teacher. There is an indirect influence of teacher classroom management knowledge on the performance of Hindu religious teacher through teacher achievement motivation and teacher competence on the performance of Hindu religious teacher.
\end{abstract}

Keywords: knowledge of classroom management, hindu religious, teacher's performance

\section{INTRODUCTION}

The development of science has an impact on all sectors including the education sector. In the education sector, starting from basic education, it is expected that all teachers in the Elementary School must be professional, namely having abilities and motivation [1]. On the other hand, the principal must have the knowledge, attitudes, and professional skill [2]. Teachers as subordinates must have the knowledge, attitudes, and professional skills, even in School-Based Quality Improvement Management requires a creative, independent teacher, and has a high level of abstraction. Teachers who have a high level of abstraction tend to always identify weaknesses in the learning process that they manage and independently try to find alternative improvements. The development of science and technology in the world of education gave birth to various approaches, methods, and new strategies in learning (Ahmad Budiyono n.d.). Similarly, the science of education unit management is always developing. The consequence of this development is that teacher professionalism must always grow and develop. Professional teachers are teachers with the right vision and innovative action. The vision without action is like a dream, but as good as action without being based on the right vision, like a trip without purpose will only waste time, vision with action must go hand in 
hand so that it can change the world of education. Therefore, in order to improve performance as a professional teacher, it is expected that teachers have sufficient management knowledge.

\section{METHOD}

The study was conducted in Tabanan Regency, with the subject/population was 370 Primary School and the population of Hindu religious teachers was 774 people. By using the Warwick and Lininger formulas, it can be anticipated and overcome the possibility of some respondents who were not returning or not filling out the questionnaire completely and correctly, so that the minimal target sample size which is equal to 260 will still be fulfilled. Based on the results of the calculation, the number of samples was 304 people. Taking into account the number of samples, then only a portion of the population directly examined in this study while drawing conclusions applies to the entire population. Therefore, the sample is representative, so that conclusions might only have a little error. Data were collected using a questionnaire. The trial of research instruments intended that the compiled instruments can be used to obtain data accurately and meet the requirements of validity and reliability. According to Sugiyono, for the trial of research instruments when conducting multivariate analysis, the number of sample members is at least ten times the number of variables studied, so in this study, the total sample of 50 people is needed because the number of research variables is five variables [3].

After testing, the results of the validity test of the items of classroom management knowledge instruments with the help of the SPSS for Windows version 16.00 program indicated that 30 items were valid. Valid classroom management knowledge instrument items were considered sufficient to capture research data. The instruments of the performance of Hindu religious teachers were 32 items, 31 items were valid instruments and 1 item was invalid. The invalid instrument item was removed and the valid instrument items were considered sufficient to capture research data[4].

The reliability of the instrument questionnaire for teacher classroom management knowledge was calculated using alpha coefficients. From the results of calculations, an alpha coefficient of 0.955 was obtained. This figure showed that teacher classroom management instruments had very high reliability, so they were worthy of being used in research. The reliability of the teacher performance questionnaire obtained by the alpha coefficient of 0.952 . This figure showed that the teacher's performance instrument had very high reliability, so it was feasible to be used in research [5].

\section{RESULT AND DISCUSSION}

\subsection{Description of Research Data}

Based on the results of calculations, the classroom management knowledge variable for Hindu religious teachers tended to be in the very good category was 176 respondents or $67.7 \%$, the rest were in a good category as many as 82 respondents or $32.5 \%$, and in the adequate category was only 2 respondents or $0.8 \%$. Teacher performance variables for Hindu religious teachers tended to be in the excellent category was 113 respondents or $43.5 \%$; in the good category as many as 136 respondents or $52.3 .1 \%$, in the adequate category was 10 respondents or $3.8 \%$, and in a bad category was only 1 respondent or $0.4 \%$.

\subsection{Data Testing}

Data distribution normality testing was carried out using the Kolmogorov-Smirnov test on classroom management knowledge scores, and teacher performance for Hindu religious 
teachers. Based on calculations using the SPSS for Windows version 16.00 program, the following results were obtained.

Tests of Normality

\begin{tabular}{|l|r|r|r|r|r|r|}
\hline & \multicolumn{4}{|c|}{ Kolmogorov-Smirnov(a) } & \multicolumn{3}{c|}{ Shapiro-Wilk } \\
& Statistic & Df & Sig. & Statistic & df & \multicolumn{1}{c|}{ Sig. } \\
\hline $\mathrm{X}$ & .047 & 260 & $.200(*)$ & .989 & 260 & .274 \\
\hline
\end{tabular}

$*$ This is a lower bound of the true significance.

a Lilliefors Significance Correction

Tests of Normality

\begin{tabular}{|l|r|r|r|r|r|r|}
\hline & \multicolumn{4}{|c|}{ Kolmogorov-Smirnov(a) } & \multicolumn{3}{c|}{ Shapiro-Wilk } \\
\cline { 2 - 7 } & Statistic & Df & Sig. & Statistic & \multicolumn{1}{c|}{ df } & \multicolumn{1}{c|}{ Sig. } \\
\hline Y & .065 & 260 & .082 & .977 & 260 & .008 \\
\hline
\end{tabular}

a Lilliefors Significance Correction

Based on the processing of test data distribution normality, a recapitulation could be made as follows.

\begin{tabular}{|l|c|c|c|}
\hline \multirow{2}{*}{ Variable } & \multicolumn{2}{c|}{ Kolmogorov-Smirnov } & \multirow{2}{*}{ Conclusion } \\
\cline { 2 - 4 } & Statistik & Sig & \\
\hline Classroom management knowledge $(\mathrm{X})$ & 0,047 & 0,200 & Normal \\
\hline Teacher performance $(Y)$ & 0,065 & 0,082 & Normal \\
\hline
\end{tabular}

Based on the requirements of normality analysis of data that if the significance value or probability value is greater or equal to 0.05 , then the data is reported normal. Conversely, if the significance value or probability value is less than 0.05 , then the data is reported abnormal. This can be seen in the Kolmogorov-Smirnov statistics above, that the significance value or probability value of the classroom management knowledge variable $(\mathrm{X})$ was 0.200 greater than 0.05 . This means that the score of the classroom management knowledge variable was normally distributed. The significance value or probability value of the performance variable of the Hindu religious teacher (Y) was 0.082 greater than 0.05 . This means that the variable performance scores of Hindu religious teachers were normally distributed.

Linear regression test was carried out by using the $\mathrm{F}$ test between the scores of classroom management knowledge variables with the performance of Hindu religious teachers. From the results of the linearity test calculation using the SPSS for Windows version 16.00 program, the following results were obtained.

\begin{tabular}{|c|c|c|c|c|c|c|c|}
\hline \multicolumn{8}{|c|}{ ANOVA Table } \\
\hline & & & Sum of Squares & Df & $\begin{array}{l}\text { Mean } \\
\text { Square }\end{array}$ & $\mathrm{F}$ & Sig. \\
\hline \multirow[t]{4}{*}{$\mathrm{Y} * \mathrm{X}$} & \multirow[t]{3}{*}{$\begin{array}{l}\text { Between } \\
\text { Groups }\end{array}$} & & 4950.195 & 36 & 137.505 & 1.723 & .015 \\
\hline & & Linearity & 2038.961 & 1 & 2038.961 & 25.549 & .000 \\
\hline & & $\begin{array}{l}\text { Deviation } \\
\text { from } \\
\text { Linearity }\end{array}$ & 2911.234 & 35 & 83.178 & 1.042 & .420 \\
\hline & Within C & & 9816.180 & 123 & 79.806 & & \\
\hline
\end{tabular}




\begin{tabular}{|l|l|l|l|l|l|} 
Total & 14766.375 & 159 & & \\
\hline
\end{tabular}

Based on the processing of the data distribution linearity test using the F Test, a recapitulation could be made as follows.

\begin{tabular}{|c|c|c|c|c|c|c|}
\hline \multicolumn{2}{|c|}{ Variable Pair } & \multicolumn{3}{|c|}{ Dev. From Linierity } & \multirow{2}{*}{ Note } \\
\cline { 1 - 5 } Independent & Dependent & $\mathrm{df}$ & Mean Square & $\mathrm{F}_{\text {count }}$ & F table & \\
\hline $\mathrm{X}$ & $\mathrm{Y}$ & 35 & 83,178 & 1,042 & 1,67 & Linier \\
\hline
\end{tabular}

Based on the results of the regression line linearity test, it was known that the relationship of independent variables to the dependent variable showed that the F-count is smaller than the F-table, then the data is expressed following a linear regression model. Thus, it could be concluded that there is a linear relationship between the classroom management knowledge variables with the performance of Hindu religious teachers[6].

\subsection{Testing of Hypotheses}

Based on the results of the study of theory and the findings of previous research, a framework could be formulated in the form of a conceptual model and at the same time the research hypothesis such as the paradigm model of relationships between variables that have been determined [7]. Based on the conceptual model, the hypothesis was tested as follows.

There is a direct influence of teacher classroom management knowledge $(\mathrm{X})$ on the performance of Hindu religion teachers (Y). Hypothesis testing using path analysis must meet the assumptions as applicable to multiple regression analysis techniques, namely linearity, data normality. Normality refers to the extent to which the value of $\mathrm{Y}$ observations relates to certain $\mathrm{X}$ values normally distributed around $\mathrm{Y}$ predictions. The linearity is related to the relationship of the value of variables ( $\mathrm{X}$ and $\mathrm{Y}$ ) which must always show a linear relationship. 3.4 Results of the Research Hypothesis

Based on the regression path analysis model the path coefficient could be determined with the help of the SPSS for Windows version 16.00 computer program, the following results were obtained.

Coefficients(a)

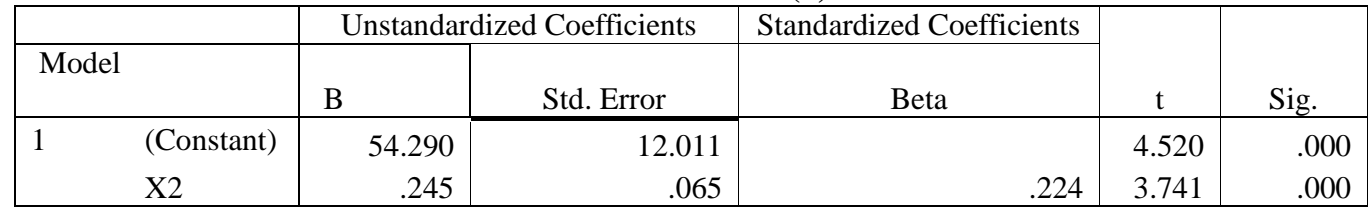

a Dependent Variable: $\mathrm{y}$

Regression : Beta $\mathrm{X}_{2}=0,224$

Based on the analysis of direct effects in accordance with the path coefficients, it can be interpreted the results of processing by taking into account the standardized regression coefficient[8], namely beta (b) which in path analysis functions as a path coefficient which is the coefficient of direct influence of Hindu teacher classroom management knowledge $(\mathrm{X})$ on 
the performance of Hindu religious teachers (Y) was illustrated with a T-count value of 3.741 greater than the T-table value of 1.96. In addition, the beta coefficient is 0.224 with $\mathrm{p}$ (probability) to showed the significance level of each corresponding path coefficient of 0.05 and the p-value of the analysis was 0.000 . Because the results of the analysis $\mathrm{p}$ were less than $0.05,(0,000<0,05)$, then $\mathrm{H} 0$ was rejected and Ha was accepted. Thus, there was a direct influence of the classroom management knowledge of the Hindu religious teachers on the performance of Hindu religious teachers. That is, the higher the classroom management knowledge of the Hindu religious teachers, the higher the performance of the Hindu religious teachers.

\subsection{Findings of Research Results}

The research findings of the influence of classroom management knowledge in improving teacher performance, based on the results of data analysis indicated that there is a direct influence of classroom management knowledge on the performance of Hindu religious teachers. With the path coefficient value can be interpreted the results of processing by taking into account the standardized regression coefficient, namely beta (b) which in path analysis functions as a path coefficient which is the direct influence coefficient of Hindu teacher classroom management knowledge $(\mathrm{X})$ on the performance of Hindu religious teacher $(\mathrm{Y})$ described with a T-count value of 3.741 greater than the T-table value of 1.96. In addition, the beta coefficient was 0.224 with $\mathrm{p}$ (probability) to show the significance level of each corresponding path coefficient of 0.05 and the p-value of the analysis was 0.000 . Because the results of the analysis $\mathrm{p}$ were less than $0.05,(0,000<0,05)$, then $\mathrm{H} 0$ was rejected and Ha was accepted. Thus, there is a direct influence of the classroom management knowledge of the Hindu religious teacher on the performance of Hindu Religious teachers in Primary Schools in Tabanan Regency. That is, the higher the knowledge of the classroom management of the Hindu religious teacher, the higher the performance of the Hindu religious teacher.

The findings of this study are in line with the findings of [9] which states that the success of education will actually occur if there is an interaction between educators and students. In this condition, the teacher plays a strategic role. All education policies, however good, will not provide optimal results, as long as the teacher does not get the opportunity to realize his pedagogical autonomy, namely the independence of the teacher in playing his function proportionally and professionally. The independence of the teacher will be reflected in the realization of the teacher's performance as a person, community member, employee, and professional teaching position. The teacher's performance is more focused on the principal's managerial abilities and teacher work motivation in an effort to improve the quality of schoolbased education. The results showed that overall the principal's managerial ability and work motivation had an effect on the performance of SLB teachers in Subang District by 54.5\%. The remaining $45.5 \%$ is the influence that comes from other factors, such as the school's organizational climate, work ethic, organizational culture, school principal's performance, satisfaction, loyalty, service, negotiation, quality, and others. Principal's managerial ability has a positive and significant effect on the performance of SLB teachers in Subang Regency. 
Stated that the impact/implications of learning innovation if carried out continuously (Biro Hukum dan Organisasi 2003), as follows.

1. The ability to solve learning problems will increase.

2. Completion of learning problems through an innovation development will improve the content, input, process, facilities/infrastructure and learning outcomes of students.

3. Capacity building in learning will ultimately have an impact on increasing personality and professionalism of lecturers and teachers to always improvise through adoption, adaptation, or creation in learning and lead to improving the quality of graduates.

Thus, the role of teachers in improving the quality of education requires an innovative attitude, because educational innovation is very great and determines the success of improving the quality of education [10]. Through the development of learning innovations or other innovations that can support learning. The increasing quality of learning hopes and goals to be able to produce graduates who are more qualified and ready and able to face competition will be realized.

Teacher performance development viewed from the perspective of performance management can be done with two approaches, namely competency-based and performancebased approaches. The competency-based approach develops performance through increasing the ability of employees/teachers to do work in accordance with their roles and tasks, while a performance-based approach develops employees/teachers through the implementation of best practices in doing work in accordance with their field of work.

\section{CONCLUSION}

Based on the results of the analysis show that the knowledge of teacher classroom management as a basis for improving teacher performance is at a good level. Knowledge of classroom management of the Hindu religious Elementary School teacher tended to be in a very good category was 176 respondents or $67.7 \%$, the rest were in a good category, namely as many as 82 respondents or $31.5 \%$, and were in an adequate category, namely 2 respondents or $0.8 \%$. This descriptive finding is very positive because most of the teachers in the research locations have very high levels of classroom management knowledge. The performance of teachers of Hinduism Elementary School tended to be in a very good category was 113 respondents or by $43.5 \%$, in a good category, namely as many as 136 respondents or $52.3 \%$, in an adequate category, which was as many as 10 respondents or $3.8 \%$ and in a less category was 1 respondent or $0.4 \%$. This descriptive finding is very positive because most of the teachers in the study locations have very high levels of performance.

Hypothesis test results (H2) are illustrated by standardized regression coefficients as path coefficients with beta coefficients of 0.224 with a T-count value of 3.741 greater than the Ttable value of 1.96. In addition, $\mathrm{p}$ (probability) to show the significance level of each corresponding path coefficient of 0.05 is greater than the p-value of the analysis of 0,000 , indicating that there is a direct influence of teacher classroom management knowledge on the performance of Hindu religious teachers. That is, the higher the classroom management knowledge of the Hindu religious teacher, the higher the performance of the Elementary 
School Hindu religious teachers. On the contrary, the lower the classroom management knowledge of the Hindu religious teacher, the lower the performance of the Elementary School Hindu religious teachers. This is consistent with Glickman's opinion that a person will work professionally when that person has the ability. That is, Hindu religious teachers are able to manage classes, able to manage learning [11].

Based on the comparative writings in this paper, it shows that professional teacher standards are basic needs that are no longer negotiable. The standard of teacher competency is something that is essential to use in measuring teacher performance to get teacher quality assurance in improving the quality of the learning process. The roles of the teacher are planners, implementers, developers, aligners, and researchers.

\section{REFERENCES}

[1] Rusman. 2010. Model-Model Pembelajaran. Mengembangkan Profesionalisme Guru. Seri Manajemen Sekolah Bermutu. Jakarta: Rajawali Press.

[2] Syamsul Bahri. 2019. Pengaruh Kompetensi Dan Aktifitas Musyawarah Guru Mata Pelajaran Terhadap Peningkatan Mutu Pendidikan Di SMP S Free Methodist Kota Medan. Medan: Faya Kunisa Guci.

[3] Sugiyono. 2006. Metodo Penelitian Kualitatif, Kuantitatif Dan RnD. Bandung: Alfabeta.

[4] Sadili Samsudin. 2006. Manajemen Sumber Daya Manusia. Bandung: CV Pustaka Setia.

[5] Rusmita, Irma, Mastar Asran, and Suryani. 2014. Korelasi Manajemen Kelas Dengan Hasil Belajar Pada Pembelajaran Ilmu Pengetahuan Sosial Di SD. Pontianak: Program Studi Pendidikan Guru Sekolah Dasar Jurusan Pendidikan Dasar Fakultas Keguruan Dan Ilmu Pendidikan Universitas Tanjungpura Pontianak.

[6] Sudarmawan Danim, and Suparno. 2009. Manajemen dan Kepemimpinan Tranformasional Kepala Sekolahan. Jakarta: Rineka Cipta.

[7] Ahmad Budiyono. Peran Guru Dalam Pengembangan Kurikulum Pendidikan Agama Islam.

[8] Ibrahim Bafadal. 2009. Manajemen Peningkatan Mutu Sekolah Dasar Dari Sentralisasi Menuju Desentralisasi. Jakarta: Bumi Aksara.

[9] Biro Hukum dan Organisasi, Setjen Depdiknas. 2003. Undang-Undang No.20 Tahun 2003. Tentang Sistem Pendidikan Nasional. Jakarta: Biro Hukum dan Organisasi, Setjen Depdiknas.

[10] Donnelly, J.H. 1995. Organisasi Dan Manajemen. Perilaku, Struktur, Dan Proses. Jakarta: Erlangga.

[11] K. Saddhono and M. Rohmadi, "A Sociolinguistics Study on the Use of the Javanese Language in the Learning Process in Primary Schools in Surakarta, Central Java, Indonesia." Int. Edu. Stu., vol. 7 no.6 pp 25-30, 2014 